\title{
FRAGMENTY DENOLOGII SLAVOJA ŽIŽKA
}

\author{
BARTOSZ WÓJCIK
}

\begin{abstract}
Abstrakt: Celem artykułu jest rekonstrukcja modelu ontologii opracowanego przez Žižka w jego ostatnich pracach filozoficznych - Less Than Nothing i Absolute Recoil. Punkt wyjścia stanowi analiza fundamentalnego dla całego projektu pojęcia den („mniej niż niczego”), które pochodzi z filozofii Demokryta i zostaje przeniesione na obszar współczesnej ontologii. W pierwszym kroku, próbuję opisać strukturę den i sformułować jego definicję (czego Žižek nie robi). W drugim kroku zarysowuję schemat i funkcję podmiotu negatywnego, który stanowi podstawowy problem dla materializmu dialektycznego Žižka. Wreszcie w trzecim kroku podejmuję próbę integracji pojęcia podmiotowości i ontologii den (nazywanej tutaj denologia) przy pomocy narzędzi z Heglowskiej dialektyki (logiki „przeciwuderzenia” oraz „zstępującejsyntezy”). Innymi słowy, z chaotycznych i fragmentarycznych analiz Žižka próbuję wydobyć minimalnie koherentny projekt ontologiczny.
\end{abstract}

Słowa kluczowe: Žižek, Hegel, ontologia, dialektyka, podmiot, nic, byt 
Slavoj Žižek jako filozof od zawsze budził kontrowersje w polu filozoficznym, spotykając się nieustannie z zarzutami o brak profesjonalizmu, naukowych kwalifikacji i metodologii, czy co być może najważniejsze - o brak własnej teorii filozoficznej. Nawet w opinii swoich „względnych” zwolenników (Hamza 2015) uchodzi raczej za błyskotliwego komentatora i interpretatora filozofii i jej okolic niż autonomicznego i suwerennego myśliciela, którego tezy dałoby się sformalizować w postaci filozoficznego systemu - tak jak chociażby w przypadku Badiou, często przeciwstawianego Žižkowi: poważny i tradycyjny filozof prezentujący własny neoplatoński system (wykładający do tego na jednej z najbardziej prestiżowych paryskich uczelni - École normale supérieure) versus słoweński clown uprawiający prowokacyjna antyfilozofię w lacanowskim stylu1. W odpowiedzi na te zarzuty i oskarżenia Žižek powiada pełen werwy: „JA proponuje pewną »ontologię: moja praca nie jest tylko dekonstrukcyjna refleksja nad niekonsystencjami innych filozofii, ona FAKYTCZNIE zarysowuje określoną »strukturę rzeczywistości«" (Žižek 2016a).

W zasadzie dwie ostatnie książki filozoficzne - Less Than Nothing i Absolute Recoil_ - jeśli czytać je zgodnie z zapowiedziami samego autora, miałyby wreszcie być długa wyczekiwana ekspozycja jego filozoficznego systemu. Oczywiście, jak łatwo się domyślić, szumne zapowiedzi nie zostały w pełni (albo wcale) zrealizowane, czego najlepszym dowodem jest cała wrzawa wokół „filozoficzności” Žižka, będąca de facto reakcją na te publikacje. Niemniej jednak na prawie półtorej tysiąca stronach, bo tyle liczą w sumie obie pozycje, nie roi się wcale od żartów i anegdot, tylko widać autentyczne próby poważnej pracy filozoficznej o systemowych ambicjach - głównie w oparciu o teksty Hegla i Lacana - która stara się wnikać w samą istotę rzeczywistości. Piszę o próbach, ponieważ nawet przy najlepszych intencjach czytelnika nie sposób wydobyć z tego chaotycznego tygla teorii -częstokroć przeklejanych z innych książek autora - spójnego i całościowego obrazu projektu ontologicznego. Z tych porozrzucanych w rozmaitych miejscach tekstu fragmentów spróbuję jednak zrekonstruować główne ramy materializmu dialektycznego Žižka, który zostaje przez niego określony mianem denologii, bo jak wierzę - w tej bałaganiarskiej skorupie tkwi racjonalne jądro, czyli warta ocalenia pozycja teoretyczna.

Pierwsze nasuwające się pytanie brzmi: co to jest denologia? Skąd taki dziwaczny termin? Žižek we wstępie do Absolute Recoil deklaruje, że celem książki jest „zakreślenie podstawowych konturów odnowionej Heglowskiej denologii (ontologii den, «mniej niż niczego«)" (Žižek 2014, 5). Pojęcie den i opierająca się nań ontologia pochodzą

\footnotetext{
${ }^{1}$ Zwięzłe podsumowanie zarzutów o antyfilozoficzność Žižka, zob. Khader 2016.

2 Žižek w swojej histerycznej nadprodukcji twórczej napisał w 2016 roku jeszcze trzecią część swojej ontologicznej trylogii Disparities, jednak pozycja ta nie będzie uwzględniana w niniejszym tekście. Zob. Žižek 2016b.
} 
z Demokrytejskiego atomizmu: to Demokryt wprowadza neologizm den na określenie atomu³. Sama genealogia tego terminu ma dla Žižka kluczowe znaczenie: starożytni Grecy posiadali bowiem dwa pojęcia oznaczające nicość, ouden i meden - pierwsze określa coś, czego nie ma, ale mogłoby być, drugie zaś odnosi się do czegoś, czego z zasady nie mogłoby być. To właśnie meden używa Demokryt na oznaczenie próżni, niebytu (w swoim słynnym twierdzeniu, że „coś/byt istnieje nie bardziej niż nicość/niebyt” - den i meden), a sam neologizm den miałby się wywodzić ze specyficznej operacji negowania dokonanej na meden, tj. subtrakcji (czyli odejmowania). $\mathrm{Na}$ czym miałoby to polegać?

To znaczy, den otrzymujemy kiedy odetniemy od meden nie cały negujący prefiks, ale tylko jego dwie pierwsze litery: meden jest med'hen, negacją hen (jedno): nie-jednym. Demokryt dociera do den przez porzucenie me, a zatem wymyśla całkowicie sztuczne słowo den. Den nie jest więc nicością bez „nic”, nie jest to po prostu coś/rzecz, ale icośćt, jakieś coś, będące jednak w obrebie niczego, jak ontologiczny żywy trup, widmowe nic-jawiące-się-jako-coś. Albo, jak to ujął Lacan „Może, nic? Nie - może nic, ale nie nic”; do czego Cassin dodała: „Chciałabym, żeby powiedział: Pas rien, mais moins que rien (Nie nic, ale mniej nižznic)” - den jest „pasażerem na gapę” każdej ontologii (Žižek 2012, 59).

W tym gęstym fragmencie (który może śmiało posłużyć za stylistyczną próbkę całej książki) Žižek wskazuje, skąd zapożycza pojęcie den i jak je rozumie - a przy okazji odsłania źródło tytułu Less Than Nothing (Mniej niż nic) -mianowicie z lacanowskiego odczytania Demokryta autorstwa Barbary Cassin (2010). Zatem den nie byłoby po prostu niczym jako negacja czegoś, tylko punktem uprzednim wobec samego sztywnego odróżnienia czegoś i niczego, preontologicznym niczym/pustka, która w jakiś sposób jednak jest - „Byt, trzeba by rzec, jest tylko prywatywnym stanem niebytu" (Wismann 2010, 65). O ile przyjąć, za Žižkiem, obowiązujący w zachodniej tradycji metafizycznej schemat creatio ex nibilo (potwierdzany przez niektóre ze współczesnych teorii kosmologicznych), to przejście od pierwotnego niczego do czegoś, ukonstytuowanej rzeczywistości, nie dokonuje się poprzez dodanie czegoś do początkowej pustki, tylko poprzez odjecie czegoś z niczego. Nic jest pustka paradoksalna, ponieważ nie w pełni pusta, gdyż poruszają się w niej owe cząstki den - preontologiczne byty - i dopiero gdy zostaną one niejako „usunięte” (przez jaką́s trzecią instancję? Same z siebie? Przez samą pustkę?), wyczyszczona zostanie przestrzeń, w której łonie może się ukonstytuować kompletna rzeczywistość, porządek czegoś-Jednego. Wyłaniają się trzy zasadnicze momenty tej

\footnotetext{
3 Zob. Skalski 2016.

4 Žižek stosuje tutaj trudną do odtworzenia w języku polskim grę słowną pomiędzy notbing (meden - nicość / nic), thing (coś, rzecz), a othing (den - icość). W zasadzie najlepiej sens tej operacji zostałby wyrażony w polszczyźnie gdyby odejmowanie nie dotyczyło pierwszej litery nicości, tylko pierwszych trzech liter, tak żeby powstała „ość” - bo jak zobaczymy den jest właśnie, według metafory samego Žižek, „ością w gardle” bytu (bone in throat). Nothing z tekstu oryginału tłumaczę w zależności od kontekstu jako nicość albo jako nic.
} 
genetycznej ontologii, a właściwie denologii: 1. den jako pseudo-coś w ramach niczego (niepełne, proto-materialne coś); 2. właściwe nic (pusta przestrzeń), z którego den zostało wymazane; 3. coś - rzeczywistość już w pełni istniejących materialnie bytów (nazywanych Jednymi), wyłaniającą się z pustki.

Ten skomplikowany i, nie ma co ukrywać, mocno niejasny schemat ontologiczny rodzi wiele pytań, na przykład: do czego służy cała ta konstrukcja - po co jakaś trzecia forma pośrednia między bytem a niczym? Po co w ogóle posługiwać się tak abstrakcyjnymi kategoriami, jak „byt”, „nic” i „,cos’”? Czemu taka a nie inna jest kolejność poszczególnych etapów - dlaczego den poprzedza nic i co to znaczy, skoro samo też jest „czymś w ramach niczego” (czy występuje tu jedno „nic” czy też dwie różne postaci „niczego”, i jak w ogóle nic/nicość może mieć postać, itd.)? Czy ten proces jest całkowicie obiektywny - wynika z dynamiki samego bytu i jego protoform (jeśli tak, to czy stoi za nim jakaś teleologia, czy jest on całkowicie przygodny?) - czy też przejścia między etapami są wynikiem działania zewnętrznej wobec nich (albo przynajmniej odrębnej) instancji, woli czy po prostu podmiotowości, która sprawia, że z niczego wyłania się coś (na wzór Boga z tradycji teologicznej)? Można się także zastanowić, na ile w ogóle zadawanie podobnych pytań ma sens, skoro dotyczą one kwestii z pozoru bardzo sztucznych i wydumanych, nawet jak na standardy filozoficznego dyskursu. Szczególnie jeśli celem filozofii jest zmiana społeczna, a Žižek nigdy tego fundamentalnego dla tradycji marksistowskiej założenia nie kwestionował ${ }^{5}$. Jeśli jednak potraktować serio ontologiczną stawkę tych rozważań, tj. przyjąć, że próba namysłu nad pytaniami nasuwanymi przez tekst Žižka może pozwolić lepiej zrozumieć złożoną strukturę rzeczywistości, w której żyjemy (co jest warunkiem koniecznym jej rewolucyjnego przekształcenia), to warto przyjrzeć się bliżej strukturze denologii.

Žižek nie ułatwia tego zadania, choćby dlatego, że bliższe zdefiniowanie sposobu rozumienia przez niego den (kluczowego pojęcia całego przedsięwzięcia) natrafia na problem, polegający na tym, że Žižek bardziej skupia się na powiększaniu eklektycznej kolekcji skojarzeń teoretycznych, które przewodzić może formuła „mniej niż nic”, niż na ujednoliceniu jej sensu. Możemy w istocie wyliczyć odesłania den do czterech odmiennych obszarów teoretycznych:

A. Pierwotnego chaosu popędów w Światowiekach Schellinga. W swojej interpretacji Žižek zauważa, że uprzednia wobec stworzonego świata, który istnieje (Existenz) jest jego tajemnicza podstawa (Grund), chaotyczno-psychotyczne uniwersum popędów, które pulsują w niezróżnicowanym cyrkulującym ruchu. Dopiero wkroczenie decyzji-podziału (Entscheidung), aktualizacja potencjalnej woli-podmiotowości, przerywa ten zamknięty

\footnotetext{
${ }^{5}$ Nawet jego słynne odwrócenie Marksowskiej jedenastej tezy o Feuerbachu tego dowodzi: realna, czyli radykalna zmiana musi zostać poprzedzona fundamentalną interpretacją rzeczywistości, która ma zostać przemieniona, inaczej zmiana staje się pseudozmianą petryfikująca jedynie panujący porządek.
} 
w sobie i atemporalny ruch popędów wprowadzając czas, rozróżnienie przeszłości i teraźniejszości: nieskończona mnogość cząstek, popędów (den) ulega kontrakcji do Jednego (zob. Žižek 1996, 14).

B. Sein (byt) otwierającego dialektyczny dyskurs Logiki Hegla. Žižek, postępując śladami Franka Rudy ${ }^{6}$, znajduje u Hegla miejsce dla przedpojęciowego chaosu (czyli właśnie den) w pierwszym zdaniu właściwej Nauki logiki (tj. w Rozdziale Pierwszym, A. Byt): „Byt, czysty byt - bez żadnych dalszych określeń” („Sein, reines Sein, - ohne alle weitere Bestimmung“") (Hegel 2011a, 86). Uwagę zwraca powtórzenie Sein, reines Sein, które miałoby sugerować, że ów „czysty byt” jest już minimalną idealizacja, oczyszczeniem pierwszego „bytu”. Różnica sygnalizowana przecinkiem jest fundamentalną różnicą pomiędzy „preontologicznym mniej niż niczym (den)” a „czystym bytem”, który jest niczym więcej i niczym mniej niż nic: ,za sprawa pierwotnego powtórzenia, ten (proto)byt zostaje usytuowany w czystym Niczym (pustym miejscu) i wtedy staje się czymś” (Žižek 2014, 385).

C. Cząstek wirtualnych w paradoksalnym polu Higgsa. Paradoks zapożyczony przez Žižka z mechaniki kwantowej sprowadza się do różnicy pomiędzy „prawdziwą” i „fałszywą” próżnią. Stan fałszywej próżni to „absolutna pustka” (wyłączone pole Higgsa) - czysta symetria bez żadnych sił i cząstek - która jest jednak utrzymywana przez jakiś minimalny wydatek energetyczny; należy wykonać wysiłek, by ustanowić próżnie/pustkę/stan spoczynku. Nic jest drogie w utrzymaniu, dlatego pole Higgsa, dążąc do minimalizacji wydatku energetycznego, zostaje włączone, tj. cząstki wirtualne (den) zostaja puszczone w ruch i przechodzimy do „prawdziwej próżni”; by zacytować Jima Holta:

Pole Higgsa jest czymś, co zawiera mniej energii niż nic. A towarzyszy mu szalone bogactwo wirtualnych czasstek, które bezustannie pojawiają się i zanikaja. Przestrzeń w stanie próżni [tj. „prawdziwej próżni” - B.W.] okazuje się ruchliwa niczym Times Square w sylwestrową noc (Holt 2014, 70).

A zatem wynika z tego sekwencja opisywana przez Žižka: „coś tańsze niż nic” = „coś mniej niż nic" = den (odpowiednik wirtualnej cząstki we włączonym polu Higgsa) (zob. Žižek 2012, 905-962).

6 Žižek powołuje się w tym miejscu na nieopublikowany referat Franka Rudy: „Dialectics, Contradiction, Iteration, Thinking by Dividing”. Drobiazgową lekturę pierwszych paragrafów Nauki Logiki - zainspirowana zarówno Ruda, jak i Žižkiem - przeprowadza Mladen Dolar w swoim znakomitym artykule „Being and MacGuffin” (Dolar 2017), którego pozycja teoretyczna jest zbliżona do denologii (mimo, iż pojęcie den w tekście się nie pojawia). 
D. Obiektu $a$. Žižek wskazuje za Lacanem na ambiwalencje związana z obiektem $a$, który z jednej strony jest „niemożliwym” obiektem-przyczyna pragnienia, który wyłania się w momencie swojej utraty (czyli jest samą pustką, zapełniana fantazmatycznymi wyobrażeniami); z drugiej zaś jest obiektem popędu. O ile pierwszy, pragnieniowy obiekt a jest zawsze już czymś utraconym, o tyle popędowy obiekt a jest samą tą utratą, jak to ujmuje Žižek ,w zwrocie od pragnienia do popędu, przechodzimy od utraconego obiektu do samej utraty jako obiektu" (Žižek 2014, 237). Obiekt popędu jako sama utrata, luka czy cięcie miałby być desygnatem den, które jest „mniej niż nic” („obiekt, który nie może zostać upozytywniony", Žižek 2014, 213).

Wreszcie, żeby sprawę nieco jeszcze skomplikować, Žižek stwierdza:

den jest nazwą pre-ontologicznego $\mathrm{x}$ wielości mniej-niż-Jednych (a zatem mniej-niżniczego), które jest jedynym dialektyczno-materialistycznym kandydatem na W-sobie. [...] Z wnętrza tej protorzeczywistości nasza zwyczajna rzeczywistość jawi się za sprawa wyłonienia się podmiotu, który konstytuuje „obiektywną rzeczywistość”: każda pozytywna rzeczywistość Jednych jest już fenomenalnym, transcendentalnie ukonstytuowanym „korelatem” podmiotu [...] (Žižek 2012, 957).

Innymi słowy, odpowiedź na pytanie o genezę rzeczywistości - tej, którą znamy i codziennie doświadczamy - i jej relację wobec form ją poprzedzających skupiać ma się wokół pojęcia den, które okazuje się nieusuwalnie powiązane z kwestią podmiotowości. Jak mają się rozmaite postaci przedontologicznego den (rozpoznane przez Žižek w różnych - bardzo odległych od siebie - kontekstach) do właściwej rzeczywistości Jednego (czyli bytu w pełni ukonstytuowanego)? A przede wszystkim, gdzie w tym całym modelu jest miejsce dla podmiotu czy chociażby jakiś form protopodmiotowych (dążenia, woli, itp.)?7

\section{Podmiotowość den}

Zrozumienie znaczenia denologii Žižka wymaga zatem gruntownego przemyślenia miejsca i roli podmiotu czy podmiotowości w tej ontologicznej strukturze. Nie tylko dlatego, że podmiot stanowi kluczowe pojęcie transcendentalnego materializmu (termin Adriana Jonhstona), który Žižek sukcesywnie realizuje od samego początku i w ramach którego mieści się omawiana denologia, ale także dlatego, że właśnie ujęty od strony podmiotowości niezbyt

7 Powyższy fragment prezentujący rozmaite znaczenia terminu den, a raczej to samo znaczenie (w sensie logicznego schematu) w rozmaitych kontekstach teoretycznych u Žižka, powstał dzięki uwagom i komentarzom Piotra Skalskiego. 
przejrzysty i chaotyczny schemat denologii może odsłonić swoje stawki i wydobyć własną istotę. Skoro dotychczasowe próby analizy denologii z abstrakcyjnego i ogólnego poziomu ontologicznego - wychodzące od samego pojęcia den jako dziwnego proto-bytu, zamieszkującego nic i jednocześnie owo nic (tyle, że już zmienione) poprzedzającego, itd. nie przyniosły dostatecznych rezultatów i pozostawiły nas z serią nierozstrzygniętych pytań ${ }^{8}$, to być może należy odwrócić perspektywę i spojrzeć na denologię od strony najbardziej problematycznego elementu całej tej konstrukcji, czyli właśnie podmiotu. Taki zabieg metodologiczny może uzasadniać także fakt, na który uwage zwrócił Johnston, że ontologia Žižka jest wstecznie wygenerowana z teorii podmiotowości (zob. Johnston 2014, 140). Innymi słowy, cała denologia została opracowana jako próba ontologicznego ugruntowania paradoksalnego i antynomicznego podmiotu - niezmiennie głównego bohatera filozofii Słoweńca.

Centralną ideą teorii subiektywności Žižka, szczególnie akcentowaną w jego najnowszych książkach, jest nierozerwalna relacja pomiotu i negatywności: niepokojąca bliskość Ja i pustki czy Niczego to wręcz emblemat jego myśli. Idea ta swoje filozoficzne źródło ma przede wszystkim u Hegla, Žižek wielokrotnie przywołuje słynne zdanie z „Przedmowy” do Fenomenologii ducha, które może posłużyć za „minimalną definicję” negatywnego podmiotu: „potęga tą duch jest tylko wtedy, kiedy patrzy negatywności prosto w oczy i zatrzymuje się przy niej. To zatrzymywanie się jest czarodziejską siłą, która przemienia ją w byt” (Hegel 2002, 320). Jaźń (Heglowski duch to jej kolektywne imię) konstytuuje się w konfrontacji z żywiołem negatywności, z którego wykuwa się dopiero podmiot - jego byt powstaje w wyniku zatrzymania się i wytrzymania w zetknięciu z siłą tego, co negatywne. Co jednak wspólnego mają ze sobą podmiotowość i negatywność, dlaczego są myślane jednocześnie?

Dla materializmu dialektycznego - który Žižek próbuje reaktywować poprzez „powrót do Hegla” - podstawowym problemem jest wyłanianie się myśli z płaskiego porządku pozytywnego bytu: w uniwersum tego, co materialne (świecie przyrody) pojawia się myśl-jaźń, nieredukowalna do swojej materialnej genezy, ponieważ wprowadzająca w materialność pewien eksces czy zakłócenie. W przyrodzie występuje więcej-niż-materialny (zob. Johnston 2014, 119) naddatek, który nie pozwala się objąć deterministyczną logiką jej praw, a nawet więcej, rozbija jej totalistyczną strukturę, dążącą do zapanowania nad wszystkim, co wyprodukowała. Dlatego

\footnotetext{
${ }^{8}$ Zresztą te nieustające pytania, które pojawiają się w związku z projektem denologicznym Žižka same w sobie mogą być dowodem jej niedostatecznej dialektyczności, odstępstwa od Heglowskich struktur myślenia. Ponieważ, jak trafnie zauważył Dolar, formuła charakteryzująca strategię filozoficzną Hegla brzmiała: „nie zadawaj pytań, ale zaczynaj od odpowiedzi. Filozofia jest sprawą konstrukcji, a nie stawiania pytań i szukania na nie odpowiedzi. Jeśli, dla zabawy, zaryzykowałbym bardzo prowizoryczny podział, to są filozofie pytania - szczególnie Sokrates, Kartezjusz, Kant i bez końca Heidegger; oraz filozofie odpowiedzi - przede wszystkim Spinoza i Hegel” (Dolar 2017, 89). Žižek, choć pragnie - w zgodzie ze swoim mistrzem - uprawiać filozofie odpowiedżi, to ze względu na niesystematyczność, chaotyczność i luki w argumentacji ostatecznie często tworzy filozofie nieustajacych pytań...
} 
różnica myśli i bytu będzie różnicą negatywności i pozytywności, nie-całości i całości. Dla Žižka zatem Jedno-byt jest zawsze już nie-całością, niedomknięta i niekompletną rzeczywistościa naruszona przez obecność myśli, której nośnikiem jest podmiot. Paradoks tej relacji polega na tym, że, jak wiemy, myśl w tradycji filozofii transcendentalnej z bezczasowego, prekonceptualnego chaosu wrażeń wytwarza dopiero uczasowioną i poznawalną rzeczywistość zjawiskowa, jednocześnie uniemożliwiając jej jedność i tożsamość ze sobą. Podmiot jest negatywnym ostrzem, które rozcina płaskie kontinuum bytu-przyrody, które to kontinuum sam wytworzył, przekształcając amorficzną mgławicę w ustrukturyzowany - wedle sieci kategorii byt. W punkcie wyjścia owo nie-całe Jedno rozpada się już na zantagonizowane dwa momenty: myśl i byt, podmiot i przedmiot, negatywność i pozytywność, immanencję i transcendencję, dla-siebie i w-sobie, itd. Dialektyczne myślenie Žižka rozpatruje konflikt czy antagonizm jako coś absolutnie pierwotnego i prymarnego, dlatego nie ma tam miejsca na Jedno sprzed podziału na dwa, na pozytywną totalność bytu niedotkniętą jeszcze negatywnym działaniem podmiotowości. Podmiot driała od samego początku, ponieważ byt od samego początku, który daje się pomyśleć, jest dysfunkcjonalny i dysharmonijny. Dlaczego? Albowiem skoro jest to początek myślany, to jest już obecny w nim podmiot (owego myślenia), wprowadzający w obręb bytu lukę i różnicę - różnicę między podmiotem/myśla i przedmiotem/bytem właśnie. Tak w skrócie rysuje się ontologia podmiotu u Žižka sprzed jego denologicznego projektu, który wprowadzi do powyższego schematu dodatkowe pojęcia i dystynkcje.

Podmiot jako negatywność stanowi klucz do właściwego zrozumienia genetycznego antagonizmu pustki, jednak zanim będzie można zbadać wzajemne relację pomiędzy den, Niczym i podmiotowościa, potrzeba pełniejszej charakterystyki samej jaźni. Žižek zręby swojej koncepcji podmiotowości opracowuje w oparciu o wykładnię Lacana oraz autorską i mocno nieortodoksyjną interpretację filozofii Hegla9 . Szczególnie wpływ tego drugiego odzwierciedla się w idei pustego czy negatywnego podmiotu, który Žižek lubi nazywać za niemieckimi mistykami i romantykami „nocą świata”10 (wycofanie się z zewnętrznej rzeczywistości do pustki czystej wewnętrzności, punktowego Ja). Dla Hegla, jak wiadomo, celem dążenia nienasyconej - bo dotkniętej negatywnościa - podmiotowości jest samowiedza, o której m.in. traktuje jego słynna dialektyka Pana i Niewolnika. Žižek pojmuje tę samowiedzę w dość zaskakujący sposób: podmiot (jak Niewolnik) musi w pełni rozpoznać się w sile, która pragnie go pochłonać, gdyż skoro sama jaźń jest negatywnością, to nie ma żadnej zewnętrznej wobec niej otchłannej mocy:

\footnotetext{
${ }^{9}$ Wyczerpującą analizę teorii podmiotowości Žižka zob. Johnston 2008.

10 Sam Hegel powołuje się na te metaforę w swoim mocno enigmatycznym i zarazem poetyckim fragmencie z Jenajskiej filozofii ducha: „Człowiek jest tą noca, tą pustą nicością, która w swojej prostocie zawiera w sobie wszystko [...]. To właśnie jest noc, tutaj istnieje wnętrze natury - ç̧ysta jaźń. W fantasmagorycznych przedstawieniach noc rozpościera się wszędzie naokoło; tu wystrzela okrwawiona głowa, tam wynurza się nagle jakaś inna biała postać i równie gwałtownie znika. Noc zobaczy ten, kto człowiekowi zajrzy w oczy - kto zajrzy w głąb nocy, która staję się strasæ̨n; tutaj rozpięta zostaje przed nami noc świata” (Hegel 2014, 57).
} 
„tym, czego [podmiot] się boi w strachu przed śmiercią, jest negatywna moc samej Jaźni” (Žižek 2012, 198). Negatywność nie ulega magicznemu obróceniu się w pozytywność, tylko zostaje rozpoznana jako źródłowa moc samego podmiotu, którą ten może znieść jedynie dzięki pełnemu utożsamieniu się z nią. Podobnie argumentuje Žižek w następującym fragmencie:

Jak zatem ta czysta negatywność czy utrata „magicznie” obraca się w nową pozytywność? Co otrzymujemy, gdy nie otrzymujemy nic w zamian? Jest tylko jedna spójna odpowiedź: sama te negatywność. Gdy nic nie wypełnia negacji, gdy jesteśmy zmuszeni do konfrontowania się z mocą negatywności w nagiej czystości i jesteśmy pochłaniani przez nią, jedynym sposobem, by trwać, jest zdanie sobie sprawy, że ta negatywność stanowi sam rdzeń naszego bytu, że podmiot ,jest” pustką negatywności. Jądrem mojego bytu nie jest jakaś pozytywna cecha, ale po prostu możliwość zapośredniczenia czy zanegowania wszelkich ustalonych określeń; nie chodzi o to, kim jestem, tylko o negatywny sposób, w jaki moge odnosić się do tego, czymkolwiek jestem (Žižek 2012, 317).

Podmiot, definiowany tym razem w ramach strukturalistycznych, jest wobec tego reprezentowany przez znak znaczacy nic, a nie nic nie znaczący: Lacan taki znaczacy nazywał „znaczącym, który reprezentuje podmiot dla innego znaczącego”. Jak to rozumieć? Każda struktura symboliczna jest wewnętrznie wybrakowana, dziurawa i ten brak jest wypełniany refleksyjnym znaczącym braku znaczącego; utożsamiając podmiot z brakiem możemy stwierdzić, że refleksyjny znaczący braku reprezentuje podmiot dla innych znaczących (zob. Žižek 2014, 411). Podmiot jest pustką, ponieważ nie ma żadnego ostatecznego referenta, a raczej to sam ten brak jest jego ostatecznym referentem; podmiot to nazwa (reprezentowana przez znaczący) dla tego braku. Jeszcze inaczej rzecz ujmując: podmiot, próbując przedstawić samego siebie w porządku symbolicznym, ponosi porażkę i jest niczym innym niż pustką (czy brakiem) pozostawiona po fiasku swojej samo-reprezentacji; pojawia się wiec wraz z utratą siebie samego. Jak wobec tego należy rozumieć paradoksalne położenie podmiotu, który wyłania się z negatywności i sam jest pustką, ale przecież jednocześnie jest podmiotem, nośnikiem określeń? Jak Ja może wyrwać się z otchłani radykalnej odnoszącej się do siebie negatywności, unicestwiającej wszelkie ustalone określenia?

Žižek, odrobiwszy lekcje transcendentalizmu, rozwiązania teoretycznego impasu poszukuje w praktycznej domenie woli i decyzji: „podmiot jako czyste Pojęcie musi swobodnie określać siebie, by ustanowić jakasś określoną partykularną treść, która liczyłaby się jako »jego własna«” (Žižek 2012, 367). Ta określona treść, która przyjmuje podmiot, jest oczywiście całkowicie arbitralna: nie ma żadnego zewnętrznego wobec Ja określenia, ponieważ wszelkie określenia pochodzą z absolutnie wolnej ekspresji tegoż Ja, to znaczy są rezultatem kompletnie subiektywnej decyzji czy wyboru. ,Jest tak, bo tak chciałem”- brzmi podstawowa deklaracja podmiotu. Nie oznacza to, że podmiot - jak w naiwnym pseudofichetańskim idealizmie transcendentalnym - jest wszechmocnym stwórcą całej rzeczywistości (to, co pomyślałem- 
zapragnąłem, to się stało), gdyż rządzi nim logika retroaktywnego ustanawiana określeń, którą najlepiej wyraża Nietzscheańska wola samoprzezwyciężenia przekształcająca każde „tak było” w ,tak chciałem”. Podmiot jako pustka samo-odniesienia (sam w sobie ustanawia to, co go określa), tj. znaczący braku, umożliwia wyłonienie się wszystkich określonych i partykularnych znaczących - w tym sensie stabilizuje nie-materialny świat sensu, rzeczywistość utkaną ze znaczeń i kategorii, wsparta na cielesnej, nieprzeniknionej materialności.

Reasumując: podmiot jako taki jest nazwą dla tego, co nie ma żadnej określonej nazwy wskazującej konkretny przedmiot czy osobę; jest „przekreślony” jak u Lacana (\$), ponieważ nie posiada żadnych stałych - tj. danych z góry - określeń. Dlatego zdaniem Žižka racja w sporze o subiektywność stoi po stronie Kartezjusza i jego abstrakcyjnej (formalnej) pojedynczości cogito, a nie po stronie posttranscendentalnych zwolenników konkretnego (wypełnionego treścia) ludzkiego bytu: „podmiot jest »abstrakcyjny«, opróżniony, paradoks rzeczywiście istniejącej abstrakcji, a całe bogactwo »konkretnej osobowości« pojawia się wtórnie, by wypełnić te pustkę" (Žižek 2014, 410). W obrazie tym brakuje jednego elementu, który Žižek wprowadza za Lacanem: „wzajemność między podmiotem i objet a jest totalna” (Lacan 2004, 168). To znaczy, że podmiot podtrzymuje zawsze jego przedmiotowy kontrapunkt, czyli obiekt a: nie da się pomyśleć subiectum bez obiektu; skoro podmiot wprowadza negatywność w byt, to - jak już wiemy - sam sobie musi być negatywnościa naznaczony, dlatego jest pustka, znaczącym braku, porażką własnego procesu przedstawienia, itd., obiekt a zaś to ślad tej wewnętrznej niemożliwości-negatywności podmiotu, który wobec tego nie jest nawet w pełni podmiotem, bo zawsze już zawiera w sobie - w najgłębszym rdzeniu - swój przedmiotowy korelat.

Naszkicowawszy Žižkowska teorię podmiotowości, spróbujmy ją włączyć w obręb denologii, która poszukuje odpowiedzi na pytanie: „Jak rzeczywistość powinna być ustrukturyzowana, żeby (coś takiego) jak podmiotowość mogło się w niej wyłonić?" (Žižek 2014, 19). Problematyczność tego zagadnienia polega zasadniczo na tym, że pytanie o strukture rzeczywistości umożliwiająca geneze podmiotowości może być zadane tylko z perspektywy tejże podmiotowości: jaźń refleksyjnie zwraca się ku swojemu źródłu, które jest w niej samej, gdyż nie ma rzeczywistości poza podmiotem. A zatem, poruszamy się w dwuznacznym i paradoksalnym obszarze myśli spekulatywnej, myśli „,na pierwszym miejscu zadającej sobie pytanie o to, co trzeba jeszrže założyć, aby było możliwe to, co jest takim, jakim qakładamy, że jest” (Sosnowski 2011, 13). W naszym wypadku rakładamy, że podmiot (tożsamy z myśla) jest pustka, negatywnościa, wprowadzająca lukę czy brak w łono bytu, który tym samym jest nie-całym Jednym, dzielącym się na dwa; albo, ujmując to w dyskursie Hegla, podmiotowość wyłania się z immanentnego antagonizmu skończonej substancji, niemogącej w zupełności stać się soba, tj. niezdolnej do osiagnięcia tożsamości-pojednania z samą soba. „Niepokojem 
negatywności”"11, rozbijającym jedność substancji i zagrażającym od wewnątrz jej stabilności jest właśnie Jaźń - zgodnie z uwaga Hegla, „eben diese Unrube ist das Selbst” („tym niepokojem jest jaźń”, Hegel 2002, 25) ${ }^{12}$. Słowem, niespokojna substancja zrazu już naznaczona jest niemożliwością, którą ucieleśnia podmiot jako negatywność. W takim razie co należy jeszçze założyć, aby powyższe założenia były możliwe, aby ów schemat mógł działać? Jakie przesłanki podmiot musi retroaktywnie ustanowić, aby był tym, czym jest? Oto moment, w którym Žižek sięga do samego źródła antagonizmu, reprezentowanego przez różnicę myśli-podmiotunegatywności i rzeczy-substancji-pozytywności, czyli do podstawy niekoherentnego i dysfunkcjonalnego bytu porysowanego ostrzem negatywności.

Podstawa antagonizmu czegoś jest antagonizm Niczego czy pustki - stanu poprzedzającego emergencję rzeczywistości, który w tradycji zachodniej metafizyki najczęściej był określany mianem nicości jako absolutnego początku. Toteż Žižek dokonuje tutaj pseudodedukcji (będącej w istocie ustanawianiem założeń podtrzymujących to, co już założone): luka w bycie, tj. antagonistyczna struktura rzeczywistości - nieistnienie wielkiego Innego odzwierciedlająca konflikt jaźni opisywany przez psychoanalizę, pochodzi od bardziej źródłowej luki w niçym, czyli od niekonsystencji czy nietożsamości samej pustki sygnalizowanej przez obecność den, „mniej niż niczego”. Sekwencja wyłaniająca się z tego schematu wygląda następująco: antagonizm Niczego powodowany przez den $\rightarrow$ antagonizm Jednego/bytu powodowany przez podmiot $\rightarrow$ antagonizm podmiotu powodowany przez obiekt $a$. Innymi słowy, podmiotowość wytwarza tę konstrukcję w celu ugruntowania własnej negatywnej istoty; próbuje opowiedzieć sobie historię swojej genezy, co sprowadza się do ogólnego pytania: skąd pochodzi antagonizm konstytutywny dla każdego z powyższych poziomów?

Žižek szukając wyjaśnienia schodzi w głąb do poziomu protorzeczywistości, w której wirują wirtualne cząstki den, ta obecność „mniej niż niczego” zakłóca spokój i harmonijną równowagę Niczego dążącego do stanu czystej pustki, „fałszywej próżni”. Pustka oz̧nacz̧a antagonizm, ponieważ sama jest naznaczona antagonizmem. W dialektycznym sensie źródłem każdego antagonizmu musi być antagonizm w samym antagonizmie, antagonizm refleksyjnie skierowany do siebie. Tu działa ważna dialektyczna reguła: antagonizm zawiera w sobie samego

\footnotetext{
${ }^{11}$ Niepokój negatywności jako fundamentalna kategoria ontologiczna, stojąca u podstaw prymatu stawania się nad bytem, pojawia się w Wykładach jenajskich Hegla i odgrywa szczególnie istotną rolę we francuskich interpretacjach Hegla (zob. np.: Koyré 2014; Nancy 2012). Jednak to Herbert Marcuse przedstawia najlepszy opis tego, na czym ów niepokój polega: „Rzeczy skończone są »negatywne« - i to je określa oraz charakteryzuje; nigdy nie są tym, czym mogą i powinny być. Zawsze pozostają w stanie, który nie odpowiada w pełni ich możliwościom. Istotą rzeczy skończonej jest »absolutny niepokój«, dążenie do tego, by »nie być tym, czym ona jest«" (Marcuse 1966, 65). Jaźń, ludzki podmiot jest synonimem owego niepokoju.

${ }^{12}$ Hegel to napięcie między podmiotem a substancją objaśnia następująco: „Nierówność, która występuje w świadomości między Ja a substancją, która jest przedmiotem świadomości, jest ich różnica, tym, co negatywne w ogóle. To, co negatywne, można uważać, za jakiś brak obu [tych momentów], ale jest to ich dusza, czyli to, co je porusza [...]. Otóż jeśli ta negatywność jawi się najpierw jako nierówność Ja wobec przedmiotu, to jest ona w tym samym stopniu nierównością substancji z sobą samą" (Hegel 2002, 34).
} 
siebie i swoje przeciwieństwo, tj. pojednanie. Podwojenie wprowadza różnicę wewnętrzną w podwajanym pojęciu, czyli czyni je nietożsamym z samym soba - ta dialektycżna zasada ma swoje ontologiczne ugruntowanie w niekonsystencji na najbardziej bazowym poziomie: w Niczym. Co to znaczy, że Nic nie jest tożsame ze sobąi wewnętrzne sprzeczne? Žižek udziela prowokacyjnej odpowiedzi, że „Nic nawet nie istnieje - jeśli poprzez »Nic« rozumiemy pierwotną otchłań, w której wszystkie różnicę są zatarte. Tym, co ostatecznie »tam jest«, to absolutna różnica, samo-odpychająca się Dziura”, a zatem „Nic jako negacja nie jest pierwotnie negacja czegoś, pozytywnego bytu, tylko negacją samej siebie” (Žižek 2012, 378). Sformułowany w ten sposób wniosek więcej nie-dopowiada niż od-opowiada. Spróbujmy zbadać, co faktycznie dzieje się w Niczym, które nie może stać się w pełni Niczym, pamiętając jednocześnie o tym, że sam język stawia opór i wpada w ekwiwokacje, gdy formalizuje nicość.

Nic jako stan początkowej pustki, symetrii czy równowagi (nazywany przez Žižka „zasadą nirwany”, zob. Žižek 2012, 132) zawiera w sobie coś, co zakłóca ten pozorny pokój i harmonię otchłani, doprowadzając do jej samo-zanegowania; elementem tym jest oczywiście den, minimalny proto-byt, który jest „mniej niż nic”: zgodnie z terminami pola Higgsa, w próżni - na najniższym poziomie energii - rozwiązaniem „tańszym” (mniej kosztownym dla systemu) jest pozostanie w ç̧ymś niż utrzymywanie niczego (wyłączone pole Higgsa, tj. „fałszywa próżnia” wydatkuje pewną energię - nic nie jest za darmo!, zob. Žižek 2014, 392). Žižek wykorzystując fizykę kwantową do charakterystyki den, może co prawda w zgrabny i efektowny sposób wyjaśnić paradoks „czegoś mniej niż niczego” i antagonizmu pustki (różnica dwóch próżni), zaciemnia jednak to, co jest przecież faktyczną stawką jego ontologii-genezę podmiotowości. W tym kontekście Žižek oferuje nam jednak niewiele: kreśli zaledwie analogię pomiędzy pozycją obserwatora w mechanice kwantowej Nielsa Bohra (obserwujące podmioty są częścią obserwowanej rzeczywistości, którą „obiektywnie” przekształcaja, zob. Žižek 2014, 932-943) a podmiotem rejestrującym antagonizm pustki/Niczego. Zostawia jednak pewne ślady i tropy, którą moga pozwolić zarysować pełniejszy obraz.

Uwage powinna zwrócić akcentowana w przywoływanych powyżej fragmentach refleksyjność czy zwrotność Niczego, które neguje samo siebie, będąc „samo-odpychająca się Dziura". Przedrostek samo- ewokuje refleksyjnie skierowany do siebie ruch, dokonujacy się w Niczym: Nic zderza się z samym sobą i rozpoznaje, że nie zachodzi w nim koincydencja czy tożsamość. Rezultatem tego podwojenia Niczego jest antagonizm, niepokój, który przekształca pustkę jako stan absolutnego wyzerowania, gdzie „nic się nie dzieje”, w dynamiczny proces, obszar konfliktu, gdzie „dzieje się wiele” - den-mniej-niż-nic ściera się z zerem-czystą-pustką. Rozwiązaniem tego antagonizmu wewnątrz pustki jest wyłonienie się Jednego, czyli czegoś; innymi słowy, jeden przychodzi, by wypełnić lukę powstała w zerze. Cały ten proces umożliwia owa pierwotna refleksyjność, czyli zwracanie się Niczego do siebie samego rozpoznającego swoją niekompletność, która jest niczym innym niż najkrótszą definicją podmiotowości: nie ma 
refleksyjności bez podmiotowości! Podmiotowość w pustce rozdzieranej przez wewnętrzny antagonizm nie jest jeszcze podmiotem w pełni uformowanym, zaktualizowana postacia świadomości, występuje ona raczej w swojej pra-formie jako ślad czy podmiotowość potencjalna (albo dążenie-do-podmiotowości), która jednie znamionuje tarcia w Niczym. Wobec tego, na najbardziej fundamentalnym poziomie, w ontologicznym punkcie zerowym niemożliwej pustki operują trzy uwikłane ze sobą nawzajem momenty: den-mniej-niż-nic, nicwłaściwe i podmiot. Choć na płaszczyźnie strukturalnej momenty te sa od siebie nieodseparowane i występuja ontologicznie jednocześnie, to Žižek, aby je uchwycić i opisać ich dynamikę, dzieli je na logiczne etapy następujące kolejno po sobie. Metoda ta przypominałaby model zastosowany przez Hegla w Nauce logiki. Skoro dialektyka jest ruchem pojęcia, to ruch ten, aby mógł zostać opisany, musi posiadać możliwą do uchwycenia - dla rozumowego spojrzenia - trajektorię, a tę wyznaczają arbitralnie wyznaczone punkty: początek i koniec. Podobnie ma się rzecz w praontologicznej pustce: rozum, aby poznać procesy w niej zachodzące, musi stworzyć pewną założeniową genetyçna narracje - która będzie miała „początek”, „koniec” i „następowanie po sobie” - konieczną dla uchwycenia strukturalnej dynamiki owej pustki. Czy skądinąd nie powracamy tutaj do spekulatywnego podmiotu ustanawiającego meta-założenia przyjętych już założeń? Žižek co prawda nigdzie explicite nie przeprowadza rozróżnienia ontologicznej symultaniczności (struktury) i logicznej konsekutywności (genezy) w odniesieniu do podstawowych pojęć denologii, ale jak postaram się uzasadnić, tylko taki zabieg pozwoli na zachowanie wewnętrznej logiki i minimalnej koherencji w jego projekcie.

\section{Spekulacja denologiczna}

Różnica ontologicznej struktury i logicznej genealogii w ramach denologii może zostać wytłumaczona tylko na tle dialektyki, która w niej pracuje - matrycy organizującej ruch pojęć, współrzędne poszczególnych schematów oraz następstwo etapów. Žižek konstruuje oś motoru dialektycznego denologii w oparciu o dwa terminy pochodzące z Heglowskiej logiki refleksjinauki o istocie: „absolutne przeciwuderzenie” (absoluter Gegenstoss - tytułowe absolute recoil) i „zstępująca-synteza” (Žižkowskie pojęcie określające logikę triady refleksji).

Pierwsze pojęcie, Gegenstoss, oznacza właśnie - jak dobrze to oddał Adam Landman w swoim przekładzie Nanki Logiki - „przeciw-uderzenie”, albo „przeciw-odbicie”, „przeciwodepchnięcie”, „kontr-rzut”:

Refleksja zastaje więc coś bezpośredniego, wychodzi poza nie i jest powrotem do niego. Ale ten powrót jest dopiero zakładaniem tego, co się zastało. To, co się zastaje, powstaje tylko dzięki temu, że się je opusžrza. [...] Ruch refleksyjny, rozpatrzony bliżej, należy zatem ujmować jako absolutne przecinvuderzenie w sobie samym. Założona przesłanka powrotu do 
siebie - to, z czego istota wraca i jako to powracanie dopiero jest - ma istnienie tylko w samym tym powrocie. (Hegel 2011, 23)

A zatem, powrót czy wycofywanie się wytwarza dopiero to, do czego powraca - ruch powrotu generuje źródło, do którego powraca. Žižek interpretuje te osobliwą dynamikę refleksji następująco:

Absoluter Gegenstoss reprezentuje zbiegnięcie się przeciwieństw, w którym działanie jawi się jako swoje przeciw-działanie, albo, bardziej szczegółowo, w którym negatywny ruch (utrata, wycofanie) sam generuje to, co „neguje”. „To, co się zastaje, powstaje tylko dzięki temu, że się je opuszcza” i jego inwersja („tylko w samym tym powrocie” pojawia się to, do czego powracamy, jak narody konstytuujące się poprzez „powrót do swoich utraconych korzeni”) są dwoma stronami tego, co Hegel nazwa „absolutną refleksją”: refleksja, która nie jest już zewnętrzna wobec swojego przedmiotu, zakładając go jako dany, tylko która, jako taka, zamyka pętlę i ustanawia swoje własne założenia. (Žižek 2014, 148)

„Absolutne przeciwuderzenie” byłoby wobec tego operatorem absolutnej refleksji, tj. syntezy refleksji ustanawiającej i refleksji zewnętrznej: przed-refleksyjny chaos zostaje zanegowany poprzez refleksję ustanawiającą źródło-podstawę, która następnie zostaje refleksyjnie ujęta jako zewnętrzna i nieuchwytna przesłanka (rzecz sama w sobie); wreszcie absolutna refleksja wpisuje zewnętrzna refleksję $\mathrm{z}$ powrotem w samo źródło-podstawę, dokonując tym samym jej wewnętrznego przemieszczenia, dezintegracji czy właśnie „przecinuderæ̨enia w sobie samym” (w konsekwencji źródło-podstawa jest wybrakowana i wyobcowana od samej siebie).

Powyższy schemat „absolutnego przeciwuderzenia” zostaje odtworzony w samym podmiocie $^{13}$ i jego relacji do substancji, bo jak pamiętamy, podmiot pojawia się wiec wraz z utratą samego siebie, to znaczy jest rezultatem niemożliwości stania się sobaj; „ podmiot jest prawda substancji: prawdą każdej substancjalnej rzeczy jest to, że jest ona retroaktywnym rezultatem swojej własnej utraty" (Žižek 2014, 150). Innymi słowy, z pozycji Heglowskiego absolutu ${ }^{14}$ podmiot nie tyle zawsze jest utracony (przekreślony, niespójny), co jest samą tą utrata:

${ }^{13} \mathrm{Na}$ uwage zasługuje interesujące pokrewieństwo pomiędzy Heglowskim Gegenstoss a Fichteańskim Anstoss (oba zawieraja dziwne słowo stoss - „wstrzą”, „kopniak”, „pchnięcie”, „uderzenie”), którego Žižek nie odnotowuje, mimo iż analizuje oba te pojęcia (interpretacja Anstoss zob. Žižek 2012, 150-156). O ile pierwsze charakteryzuje logikę negatywnego podmiotu wyłaniającego się z własnej utraty (wytwarzającego się jako rezultat porażki stania się soba), o tyle drugie oznacza pierwotny impuls samo-ograniczający i samo-określający pusty podmiot, czyli obiekt a jako nieprzyswajalne obce ciało naruszające jego jedność i tożsamość ze soba. Anstoss wstrząs Realnego wewnątrz podmiotu - byłoby więc przedmiotowym korelatem Gegenstoss, podmiotu jako przeciw-uderzenia w substancji.

14 Žižek (idąc zresztą za rozpoznaniem Catherine Malabou - zob. Malabou 2005, 156) pojmuje Heglowski absolut etymologicznie jako łacińskie absolvere: uwalnianie, odpuszczanie (absolucja jako odpuszczenie grzechów) czy roz-wiązanie mające niemiecki odpowiednik w ent-schliessen, oznaczającym decyzję. W systemie Hegla kontekstem dla absolutu jako „decyzji o uwolnieniu” jest oczywiście zwieńczenie Logiki, gdzie idea decyduję się puścić z siebie wolno przyrodę (świat zewnętrzny) w jej własnej postaci, ustanawiając tym samym właściwego ducha 
powstaje tylko poprzez utratę samego siebie, wycofując się z siebie do siebie powraca, dlatego, że absolut oznacza tutaj przeciwuderzenie: „tym co »absolutne« jest samo to zbieganie sie ze soba wycofywania się-z i stwarzania" (Žižek 2014, 380). Możemy zatem przyjać, że dialektyka „absolutnego przeciwuderzenia”15 stanowi dla Žižka logiczną matrycę podmiotowości absolute recoil to nic innego jak nazwa fundamentalnego procesu podmiotu. W takim razie oś dialektyki Žižka z jednej strony wspiera się na podmiocie. Co stanowi jej drugi punkt podparcia?

W tym miejscu należałoby wyjaśnić drugi z terminów, tj. „zstępująca-syntezę” (,downward-synthesis”). Žižek wymyśla to pojęcie bazując na rozróżnieniu, zaproponowanym przez Jennifer Bates w Hegel and Shakespeare on Moral Imagination, „znoszenia-Aufhebung” i jego podwojenia „anty-Aufhebung” (Bates 2009, 55-85): Bates jako exemplum owej dystynkcji podaje ducha, który z jednej strony jest czystą myśla-pojednaniem (spirit), a z drugiej zaś zjawa, widmem nierozwiązanej sprzeczności (ghost); spirit i ghost odzwierciedlają dwa modele „,negacji negacji” - pozytywnego znoszenia/idealizacji (uduchowienia) oraz negatywnego inercyjnego oporu wobec postępu Aufhebung (widmowej zjawy nie-do-zniesienia). W wersji Žižka „Zstępująca-synteza” ma odpowiadać temu drugiemu modelowi „negacji negacji”, znoszenia bez pozytywnego rezultatu.

Podstawowym przykładem realizacji tej dziwnej logiki miałoby być Chrześcijaństwo, a dokładniej rzecz ujmując figura Chrystusa (podstawowy „przykład przykładów” dla Hegla): umęczony i upokorzony „syn człowieczy”, który zostaje ukrzyżowany jak pospolity przestępca, właśnie poprzez swoją nędzną ziemską postać odsłania najwyższą istotę boskości. Krzyż jest symbolem odwrócenia (Umkherung), czyli promiennego prz̨emienienia (verklärt) tego, co w sensie społecznym najbardziej zhańbione (ukrzyżowanie złoczyńcy), w to, co najbardziej wzniosłe (sztandar przyszłego Królestwa Bożego). W ten sposób funkcjonuje „chrześcijańska wzniosłość": mizerne ziemskie ciało jest forma jawienia/uobecnienia się czystej duchowości.

Ta „chrześcijańska wzniosłość” pociaga za sobą specyficzny model ruchu dialektycznego, który tutaj nazywamy „zstępującą-syntezą": finałowym momentem nie jest triumfująca „synteza”, tylko najniższy punkt, w którym wspólny grunt ustanawiania i negacji zostaje zatarty. Utknęliśmy zatem z resztką, która wypada z porządku symbolicznego: porządek uniwersalnego symbolicznego zapośredniczenia niejako zapada się w swoim inercyjnym odmęcie (Žižek 2014, $337)$.

\footnotetext{
jako rozwijającego się poza przyrodą (zob. Hegel 1990, 258). Uwalnianie przyrody jest w tym sensie wewnętrznym samo-zniesieniem ducha, koniecznym i integralnym momentem jego własnej konstytucji.

15 Jak słusznie argumentuje Borna Radnik, logika „absolutnego przeciwuderzenia”, charakteryzująca naturę ducha, reprezentuje także proces wiedzy absolutnej: gdy duch osiaga wiedzę absolutna, świadomość rozpoznaje retroaktywnie, że za każdym razem gdy konfrontowała się z wyobcowanym wobec niej Innym (historią tych zmagań jest Fenomenologia ducha), w rzeczywistości konfrontowała się z samą sobą w swoim samowyobcowaniu, w momencie ,przeciwuderzenia w sobie samym”. Zob. Radnik 2017, 359-361.
} 
Logika „zstępującej-syntezy” przybiera kształt triady: pozytywne-negatywne-sad nieskończony; uniwersalność zapośredniczenia wspiera się na partykularności bezpośredniej resztki. Innymi wielokrotnie przywoływanymi przez Žižka inscenizacjami tej matrycy u Hegla są np. dialektyka frenologii z Fenomenologii ducha (której kodę stanowi słynny „,sąd nieskończony” Die Geist ist ein Knochen, Hegel 2002, 222 - koincydencja czystego ducha-absolutu z inercyjna niedialektyzowaną resztka, kościa) oraz figura monarchy z Zasad filozofii prawa: z jednej strony Państwo stanowi racjonalną totalność znosząca przygodność indywidualnych celów, jednak z drugiej strony - tu dokonuje się dialektyczna zmiana perspektywy - okazuje się, że totalność Państwa rozumu może się urzeczywistnić tylko dzięki Monarsze jako irracjonalnej, przygodnej i cielesnej egzystencji16. Generalnie triada „zstępującej-syntezy” egzemplifikuje niepowodzenie ruchu refleksyjnego, który w swoim dążeniu do całkowitego zapośredniczenia (zmediatyzowania każdej napotkanej na swej drodze bezpośredniości) zderza się z oporem niedialektyzowalnej, tj. nie-refleksyjnej przygodnej resztki utrzymującej w ryzach cały ten złożony proces refleksji (tą metarefleksją o niemożliwości pełnej refleksyjności jest Heglowska „refleksja określona”). Należy właściwie zrozumieć paradoksalny status resztki, stanowi ona bowiem klucz do dialektyki Žižka: resztka jako „ość-w-gardle” (np. kość ducha z frenologii) jest „podwójnym wiązaniem” (double bind) dialektycznego procesu, jednocześnie warunkiem jego możliwości i warunkiem niemożliwości; „ość nie jest po prostu przeszkoda, która nie może zostać zniesiona ale, właśnie jako taka, jest pozytywnym warunkiem ruchu znoszenia przeszkodą retroaktywnie wytwarzającą to, czego jest przeszkodą" (Žižek 2014, 33).

Ość-w-gardle, resztka, przeszkoda, bezwładność cielesności, bezpośredniość przygodnego istnienia, itd. - czy to wszystko nie są pseudonimy obiektu $a$, tego małego kawałka Realności rozbijającego całość rzeczywistości? Dialektyka „zstępującej-syntezy” stanowi logiczny model Lacanowskiego Realnego, naznaczonego podwójną niemożliwością: jest bowiem czymś niedostępnym, zawsze wymykającym się naszym próbom pochwycenia i zarazem czymś, czego nie możemy się pozbyć, co chodzi za nami jak cień. Podwójna niemożliwość opowiada logice podwójnej negacji, realizującej triadę „zstępującej-syntezy”: 1. Pozytywność - jouissance jest dostępna (fantazja podmiotu o możliwości doznania pełnej rozkoszy); 2. Negatymnosí - jouissance zostaje zanegowana i tracimy do niej dostęp (podmiot

16 Zob. Hegel 1969, 277-278. W zasadzie Žižek ma jeszcze trzeci „ulubiony” przykład Heglowskiego sądu nieskończonego szczególnie dobrze wpisujący się w jego lacanowskie upodobania - mianowicie falliczna metafora kończaça rozdział Fenomenologii ducha o „Rozumie obserwujacym”. Hegel mówi tam o połączeniu tego, co wysokie i niskie, „które przyroda [realizuje - B.W] w sposób naiwny w zwierzęciu, w połączeniu organu, dzięki któremu osiaga ono swoje ostateczne, najwyższe spełnienie [des Organs seiner höchsten Vollendung] - organu płodzenia $-z$ organem siusiania. - Sądem nieskończonym jako nieskończonym byłoby ostateczne spełnienia życia, które samo siebie ujmuje, a świadomość tego, [jako] pozostająca w sferze wyobrażenia, jest czymś tego rodzaju, jak siusianie" (Hegel 2002, 232). Słoweniec z dużym upodobaniem posługuję się tą logika, nawet tam, gdzie trudno byłoby się tego spodziewać, np. w jego dialektycznej analizie stosunku seksualnego, struktura spekulatywnego sądu nieskończonego przysługuje seksowi analnemu, w którym dochodzi do „krótkiego spięcia” defekacji i inseminacji, tego, co najniższe i tego, co najwyższe... (Zob. Žižek 2006, 13). 
konfrontuje swoją fantazję z realnością i rozpoznaje jej niemożliwość); 3. Sad nieskończony jouissance zostaje odzyskana jako coś niemożliwego acz koniecznego (podmiot nie może uciec od swojej fantazji o rozkoszy, pomimo świadomości jej niemożliwości). Czym jest w istocie ta podwójnie niemożliwa jouissance?

Jouissance nie nie istnieje - co nie oznacza, że po prostu istnieje - tylko obstaje w swoim pre-ontologicznym stanie. Objet a nie jest nie-czymś - co nie oznacza, że jest czymś; jest raczej mniej niż niczym, neguje nie tyle nic, co całe pole niczego-i-czegoś - nic jest mniejniż-niczym obserwowanym z formalnego pola czegoś. Czy Realne podwójnej niemożliwości nie jest zatem przypadkiem zstępującej-syntezy, negacji treści-formy? (Žižek 2014, 344)

„Zstępująca-synteza” opisuje przeto mechanikę działania obiektu a (oporna resztka wstrzymująca i tym samym napędzająca dialektykę zapośredniczenia). W ten sposób udało się skompletować oś dialektyki Žižka wspartej na dwóch uzupełniających się strukturach: „absolutnym przeciwuderzeniu” i „zstępującej-syntezie”, czyli, jak zostało pokazane, na korelacji podmiotu $\$$ i jego przedmiotowego kontrapunktu obiektu $a$. W jaki sposób dialektyka ta pracuje w denologii?

Ruch dialektyczny u Žižka przebiega według trajektorii „zstępującej syntezy”, która nazwiemy triadq logičnna: pozytywność-[negacja]-negatywność-[negacja negacji]-sąd nieskończony. Schemat ten zostaje zrekonstruowany w denologii:

najpierw coś zostaje zanegowane i otrzymujemy nic; następnie, w drugiej negacji, otrzymujemy mniej niż nic, nawet nie nic - nie tyle Coś zapośredniczone przez nic, co pewien rodzaj pre-ontologicznej niekonsystencji, która wprowadza brak w zasadniczą czystość Pustki.[...] Nie chodzi o to, że Pustka jest zawsze już zakłócona, ale o to, że Pustka jest wtórnym, retroaktywnym rezultatem swojego własnego zakłócenia (Žižek 2014, 343).

Wychodzimy tutaj z pozycji podmiotu-w-świecie, któremu dany jest pozytywny byt/rzeczywistość; w drugim kroku ów byt zostaje zanegowany i podmiot konfrontuje się z Niczym/pustką (znajdujemy się na poziomie dialektyki bytu i niczego z początku logiki Hegla), która jednak jest immanentnie niemożliwa, ponieważ zawsze już narusza ją den, mniejniż-nic ${ }^{17}$ (pierwotna pustka - fałszywa próżnia - jest podtrzymywana przez minimalny, wirtualny kawałek Realnego, den - prawdziwą próżnię). Z dialektyki tej wynika sąd nieskończony: pustka jest den - czyste nic wspiera się na mniej-niż-niczym. Logika kroków z powyższego opisu formuje triade fenomenologična: coś-[negacja]-nic-[negacja negacji]den. Dlaczego fenomenologiczną? Ponieważ sekwencja ta odnosi się do refleksji podmiotu,

17 Jak precyzuje Žižek: „«mniej niż nic» nie jest właściwie pustką, ale minimum treści, które funkcjonuje jako »ość w gardle« destabilizująca pustkę" (Žižek 2014, 343; p. 26). 
który w swoim doświadczeniu bycia-w-świecie musi rozpocząć od czegoś - danej rzeczywistości - aby po przeprowadzeniu podwójnej operacji negowania mógł dotrzeć do den (subtrakcji od Niczego), prymarnego zakłócenia, owej ości trzymającej w ryzach dialektykę bytu i niczego.

Skoro triada fenomenologiczna odnosi się do ontologii widzianej od strony podmiotu (punktem wyjścia jest doświadczenie), to aby zbudować ontologiczna genezę owego podmiotu, trzeba odwrócić te relację i skonstruować nowy schemat, w którym Ja rzucone w świat będzie punktem dojścia. Ten wariant zostaje rozwinięty przez Žižka w finale Absolute Recoil, gdzie próbuje on ostatecznie uporządkować swoje denologiczne rozważania, chociaż jak już wiemy, wciąż nie będzie to satysfakcjonujący obraz i będzie wymagał on istotnego spekulatywnego uzupełnienia. Póki co, sprawy z ontogenezą mają się jednak tak:

Poziomem-zero, punktem wyjścia, nie jest zero, tylko mniej niż zero, czysty minus bez pozytywnego terminu w odniesieniu, wobec którego mógłby funkcjonować jako brak/eksces. Nic (pustka) jest zwierciadłem (obrazem), poprzez który mniej niż nic ukazuje się jako coś, poprzez który pre-ontologiczny chaos ukazuje się jako ontyczne byty (Žižek 2014, 413).

Przedstawiony ruch układa się w triade genealogicznal ontologicz̨na: den-[negacja]-nic-[negacja negacji]-coś. Na początku ontogenezy mamy niemożliwą pustkę, którą rozdziera antagonizm „mniej niż niczego” (pre-ontologicznego chaosu den) i jego negacji „czystego Nic” (pierwotniej harmonii i symetrii pustki); napięcie to (różnica dwóch próżni w fizyce kwantowej) zostaje rozwiązane poprzez zanegowanie właściwej pustki (tj. negacji den), w wyniku której wyłania się coś-Jedno, czyli rzeczywistość. Ponieważ owo Jedno stanowi „negację negacji” den, to jest już nieredukowalnie naznaczone niekompletnością i negatywnością owego „mniej niż niczego”, która aktualizuje się na poziomie Jednego jako obiekt $a$, ekscesywny suplement zakłócający konsystencję rzeczywistości. Konkluzją tego procesu wyłaniania się czegoś z antagonizmu Niczego jest sąd nieskończony: Jedno jest a - totalność rzeczywistości wspiera się na nieprzeniknionym, nie-dialektyzowalnym suplemencie (obiekt $a$ reprezentuje den po stronie Jednego).

Spróbujmy połączyć ze sobą wszystkie trzy triady, aby zbudować z nich spójna opowieść, ustanawiająca relacje, jakie miałyby pomiędzy nimi zachodzić, czego Žižek niestety nie robi. Punkt wyjścia w badaniu ontogenezy - pytanie o źródło antagonizmu w rzeczywistości - dla filozofa transcendentalnego musi stanowić podmiot owego badania, nie ma bowiem bezpośredniego dostępu do rzeczywistości obiektywnej. Wobec tego zaczynamy od triady fenomenologicznej: aby podmiot w swojej refleksji mógł natknąć się na den (pre-ontologiczną niekonstystencję, czyli pra-antagonizm) zmuszony jest zanegować byt (coś-rzeczywistość), czego rezultatem jest nic, które w drugim kroku ponownie neguje i zostaje z mniej-niż-niczym. Teraz pojawia się pytanie: dlaczego potrzebna jest druga negacja, dlaczego nie można zadowolić 
się Niczym/pustką jako prostą negacją bytu? Dlaczego samo Nic jako podstawa czegoś nie wystarcza? Odpowiedzi udziela dialektyka „zstępującej syntezy” (tj. triada logiczna) ${ }^{18}$ : dialektyka bytu i niczego, przechodzących w siebie nawzajem momentów, jest podtrzymywana przez inercyjną, nie-dialektyczną resztkę mniej-niż-niczego (ości w gardle, den), która znajduje się wewnatrz samej tej dialektyki. Na najbardziej fundamentalnym poziomie ,jest” zakłócenie, przeszkoda czy dziura, która uniemożliwia Niczemu stać się w pełni niczym, naruszając jego stabilność i spójność. Schemat wyglądałby następująco: byt nie jest w pełni bytem - narusza go Nic; owo Nic samo w sobie nie jest Niczym, gdyż jego czyste nie-bycie jest zakłócone przez „coś mniej niż owo Nic” (tak jakby Nic refleksyjnie kierowało się do samego siebie i rozpoznawało, że jest coś poza nim samym, tj. właśnie ów ruch refleksji, który wykonuje, a zatem „coś jako den” byłoby rezultatem refleksyjnego podwojenia się samego Niczego). W tak zarysowanym modelu triada genealogiczna byłaby wydedukowana z fenomenologicznej, za pośrednictwem logiki, a więc cały porządek dedukcji wyglądałby tak: fenomenologia-logika-genealogia(ontologia). Podmiot-w-świecie zadaje pytanie, jak wziął się byt z niczego; żeby wyjaśnić tę dynamikę opracowuję paradoksalną logikę-dialektykę, przy pomocy której konstruuje ontogenezę: byt wyłonit sie z. Niczego, bo w samym Niczym było coś z bytu, czyli jakieś Nic zajmujące formalne miejsce bytu (,nic jest mniej-niż-niczym obserwowanym z formalnego pola czegoś”).

Brakującym elementem tych formalizacji jest główny zainteresowany, czyli sam podmiot, albowiem w żadnej z triad nie występuje jako wyodrębniony i autonomiczny moment. Dlaczego podmiotowość nie ma swojego przypisanego, jednego miejsca na żadnym z tych poziomów i etapów? Czemu podmiot pozostaje jakby w ukryciu? Dzieje się tak, ponieważ jest on warunkiem możliwości wszelkiej formalizacji: logiçne fazy następowania po sobie (zobrazowane w poszczególnych triadach) są puszczane w ruch przez strukturalny mechanizm, którym porusza dziwny impuls, ,przeciwuderzenie w sobie samym” - czyli po prostu podmiot. Całość tych skomplikowanych przejść, odwróceń, podwojeń, itd. dokonujących się w denologii jest możliwa tylko dlatego, że zaws ze już dzৃała w nich forma podmiotowa. Dialektyka „zstępującejsyntezy", logika obiektu a, która stanowi model procesu ontologii den, ma wszakże swój kontrapunkt w \$, przekreślonym podmiocie, czyli „absolutnym przeciwuderzeniu” uruchamiającym sam ten proces zstępowania od pozytywności do sądu nieskończonego, zawieszającego opozycje pozytywność-negatywność. Podmiot inicjuje ruch całej dialektycznej maszynerii, którą zmuszony jest zatrzymać, aby poznać jej wewnętrzną mechanikę, momenty,

18 Podobnej odpowiedzi udziela także kabała Izaaka Lurii, według której Bóg na początku stworzył Nic, puste miejsce, które wydzielił z siebie w akcie kontrakcji (samo-ograniczenie czy samo-upokorzenie się Boga), by zapełniły je inne dopiero inne byty (zob. A. Bielik-Robson, The God of Luria, Hegel, Schelling. The Divine Contraction and Modern Metaphysics of Finitude, tekst nieopublikowany). Žižek, przyjmując pogląd Lurii, zwraca uwagę, że aby coś mogło się wyłonić, pre-ontologiczne Nic (chaos den) musi zostać zanegowane, zredukowane do czystego Nic - pustej tablicy, na tle której mogą się pojawić byty. 
które ja konstytuują. Innymi słowy, chociaż logika denologii sugeruje, że istnieje rzeczywistość przed-podmiotowa (pierwotny chaos wirtualnych cząstek), z której dopiero jaźń się wyłania, to jej struktura wyraźnie wskazuje, że podmiotowość zawsze już tam była, nawet jeśli w jakieś proto-formie: „\$, rodzaj zakłócenia [glitch] w pre-ontologicznym polu, wyzwalającym ontologiczną aktualizację" (Žižek 2014, 415). Podmiot konstruuje całą tę narrację o swoim pochodzeniu z den, wytwarza swoja przesłankę, stan go poprzedzający, tylko po to, by dojść do prawdy o samym sobie, którą teraz odsłoniliśmy - że był od samego początku i retroaktywnie wygenerował swoja genezę. Brak podmiotu w tej opowieści genetycznej był tylko mocniejszym zaakcentowaniem jego obecności, bo jak sugeruje nam jedna z lekcji dialektyki, brak sam może byćpozytywnq cecha. 


\section{Wykaz literatury}

Bates, Jennifer. 2009. Hegel and Shakespeare on Moral Imagination. Albany: State University of New York Press.

Cassin, Barbara. 2010. „L'ab-sens, ou Lacan de A à D”. W Alain Badiou, Barbara Cassin, Il n'y a pas de rapport sexuel. Deux leçons sur «L'Étourdit» de Lacan, Paris : Fayard: 11-99.

Dolar, Mladen. 2017. „Being and MacGuffin”. Crisis \& Critique 4/1: 83-102.

Hegel, Georg Wilhelm Friedrich. 1969. Zasady filozofii prawa. Tłum. Adam Landman, Warszawa: PWN.

Hegel, Georg Wilhelm Friedrich. 1990. Encyklopedia nank filozoficznych. Tłum. Światosław Florian Nowicki. Warszawa: PWN.

Hegel, Georg Wilhelm Friedrich. 2002. Fenomenologia ducha. Tłum. Światosław Florian Nowicki. Warszawa: Aletheia.

Hegel, Georg Wilhelm Friedrich. 2011a. Nauka logiki. T.1. Tłum. Adam Landman. Wstęp Marcin Pańków, Warszawa: PWN.

Hegel, Georg Wilhelm Friedrich. 2011b. Nauka logiki. T.2. Tłum. Adam Landman. Warszawa: PWN.

Hegel, Georg Wilhelm Friedrich. 2014. „Wykłady jenajskie. Filozofia ducha”. Tłum. Piotr Graczyk. Kronos 4(31): 56-72.

Holt, Jim. 2014. Krótka historia niczego. Tłum. Mariusz Gądek. Warszawa: PWN.

Johnston, Adrian. 2008. Žižek's Ontology: A Transcendental Materialist Theory of Subjectivity. Evanston: Northwestern University Press.

Johnston, Adrian. 2014. Adventure in Transcendental Materialism. Dialogues with Contemporary Thinkers. Edinburgh: Edinburgh University Press.

Khader, Jamil. 2016. „Review of Repeating Žižek”, SCTIW Review, August 23, 2016. http://sctiw.org/sctiwreviewarchives/archives/1194 .

Koyré, Alexandre. 2014. „Hegel w Jenie”. Tłum. Piotr Herbich i Konstanty Szydłowski. Kronos 4(31): 73-101.

Lacan, Jacques. 2004. Encore. Tłum. Cormac Gallagher. http://www.lacaninireland.com/web/wp-content/uploads/2010/06/Book-20Encore.pdf.

Malabou, Caterine. 2005. The Future of Hegel. Plasticity, Temporality and Dialectic. Tłum. Lisabeth During. Wstęp Jacques Derrida. London: Routledge.

Marcuse, Herbert. 1966. Rozum i rewolucja. Hegel a powstanie teorii społecənej. Tłum. Danuta Petsch. Łódź: Książka i Wiedza.

Nancy, Jean-Luc. 2012. Hegel: The Restlessness Of The Negative. Tłum. Jason E. Smith, Steven Miller. Minneapolis: University of Minnesota Press.

Radnik, Borna. 2017. „The Absolute Plasticity of Hegel's Absolutes”. Crisis \& Critique 4/1: 353-376.

Repeating Žižek. 2015. Red. Agon Hamza. Posł. Slavoj Žižek. Durham and London: Duke University Press. 
Skalski, Piotr. 2016. „Demokryt i zasada nieokreśloności”. Praktyka Teoretycz̨na 3 (21).

Sosnowski, Maciej. 2011. Pokochać dialektykę. O pojeciu miłości w filozofii spekulatywnej z. nieustajacym odniesieniem do Sorena Kierkegaarda. Kraków: Universitas.

Wismann, Heinz. 2010. Les Avatars du vide. Démocrite et les fondements de l'atomisme, Paris: Hermann.

Žižek, Slavoj. 1996. The Indivisible Remainder: Essays on Schelling and Related Matters, LondonNew York: Verso.

Žižek, Slavoj. 2006. The Parallax View, Cambridge (MA)-London: MIT Press.

Žižek, Slavoj. 2012. Less Than Nothing. Hegel and The Shadow of Dialectical Materialism, LondonNew York: Verso.

Žižek, Slavoj. 2014. Absolute Recoil. Towards a New Foundation of Dialectical Materialism, LondonNew York: Verso.

Žižek, Slavoj. 2016a. „Am I a Philosopher?”. http://zizek.uk/slavoj-zizek-am-i-aphilosopher/.

Žižek, Slavoj. 2016b. Disparities. London: Bloomsbury Academic. 
Bartosz Wójcik - filozof, materialista dialektyczny, asystent w Instytucie Studiów Politycznych PAN. Przygotowuje doktorat poświęcony filozofii społecznej Hegla.

\section{DANE ADRESOWE:}

Instytut Studiów Politycznych PAN

Polna 18/20, 00-001 Warszawa

EMAIL: bartosz.k.wojcik@gmial.com.

FINANSOWANIE: Praca naukowa finansowana ze środków Narodowego Centrum Nauki realizowana w ramach projektu "Filozofia negatywności Hegla i Žižka". Projekt nr 2016/21/N/HS1/03514.

CYTOWANIE: Wójcik, Bartosz. 2016. Fragmenty denologii Slavoja Žižka. Praktyka Teoretyczna 3 (21): 209-231.

DOI: $10.14746 /$ prt.2016.3.11

\section{AUTHOR: Bartosz Wójcik}

TITLE: Fragments of Žižek's Dentology

ABSTRACT: This article reconstructs the ontology of Slavoj Žižek's last two philosophical books - Less Than Nothing and Absolute Recoil. It begins with an analysis of the concept (fundamental for the whole project) of the den, "less than nothing", which comes from the philosophy of Democritus and was implemented by Žižek into the discourse of contemporary ontology. First, the article describes the structure of the den and tries to formulate its definition (which Žižek never did). Next, it outlines the scheme and function of the negative subject, which is the essential issue for Žižek's dialectical materialism. Finally, it attempts to integrate the notion of subjectivity with the ontology of den (i.e. dentology) by using concepts from the Hegelian dialectic (the logic of "recoil" and "downward-synthesis").

KEYWORDS: Žižek, Hegel, ontology, subject, dialectic, nothing, being 